\title{
THE GENETICAL CONTROL OF RADIOSENSITIVITY
}

\section{SEEDLING CHARACTERS IN TOMATO}

\author{
D. ROY DAVIES \\ Wantage Research Laboratory (A.E.R.E.), Berks
}

\section{INTRODUCTION}

Received 22.vii.6!

THovgr the existence of genetic variation in radiosensitivity within species of both plants and animals has been recognised for some time, in only a few instances has an analysis been attempted of the nature of the genetical control of this character. Grahn in a series of studies of acute and chronic irradiation toxicity in mice has shown that in this species, radiosensitivity is a continuously distributed variable (see Grahn, 1958). Smith (1942), on the other hand, has reported a major gene affecting sensitivity in Triticum monococcum. In the absence of any detailed information on this topic an analysis of the genetical control of radiosensitivity was attempted.

\section{MATERIALS AND METHODS}

A rapid and efficient method of obtaining an overall picture of the genetical control of continuously distributed variables has been developed by Jinks and Hayman (1953) and Jinks (1954). It involves an analysis of data from a set of diallel crosses between a number of inbred lines, and this was the technique adopted in the present instance for analysing the genetical control of radiosensitivity in six tomato varieties. The six varieties chosen were : (1) Harbinger, (2) Early Market, (3) Essex Wonder, (4) Ailsa Craig, (5) Hundredfold and (6) Carter's Sunrise. These were crossed in all possible combinations, including reciprocals, and the parental and $F_{1}$ seed used in the experiments. Seeds were equilibrated over calcium chloride for seven days in order to standardise their water content, and were then exposed to 28, I I 6 rads of ${ }^{80} \mathrm{Co}$ gamma rays at a rate of 2000 rads per hour. The plants were grown throughout in a heated greenhouse and planted in four blocks, each block consisting of 36 plots. The plots were divided into two sub-plots, one having 7 controlled and the other 7 irradiated plants of a given genotype. The characters scored were the distance from the apex of one cotyledon to the apex of the other at the 12th day, and the lengths of the first and second leaves at the $19^{\text {th }}$ day after sowing.

\section{RESULTS}

\section{(i) Radiation sensitivity}

An analysis of radiosensitivity could not be immediately undertaken using the differences between the means of the irradiated and control plants for each genotype, as it was found that a linear relationship existed between this difference and the size of the control plants. This correlation had to be removed in order to obtain a true measure of the radiosensitivity of the plants. A regression was fitted to the observations relating this difference between control and irradiated 
plants and the control height, in each block independently. The regressions were similar over all blocks. The deviations of the observed values from the expected values on these regression lines will be independent of the control measurements, and these were then used as the metric in the analyses. Positive values of deviations indicate radiosensitive, and negative values radioresistant genotypes. These deviations, summed over the four blocks for the three characters scored, are given in table I. These results were analysed in two

TABLE :

The mean values for radiosensitivity. The first refers to the cotyledons, and the second and third to the first and second leaf measurements respectively

\begin{tabular}{|c|c|c|c|c|c|c|}
\hline & \multicolumn{6}{|c|}{ Male } \\
\hline & I & 2 & 3 & 4 & 5 & ii \\
\hline$\underset{i}{\text { Female }}$ & $\begin{array}{r}-2.50 \\
0.85 \\
2.10\end{array}$ & $\begin{array}{l}-3.9^{8} \\
-3.4^{8} \\
-5.5^{8}\end{array}$ & $\begin{array}{l}2 \cdot 38 \\
2 \cdot 08 \\
1 \cdot 53\end{array}$ & $\begin{array}{l}2 \cdot 80 \\
9 \cdot 28 \\
7 \cdot 65\end{array}$ & $\begin{array}{l}-6 \cdot 4^{8} \\
-4 \cdot 20 \\
-4 \cdot 28\end{array}$ & $\begin{array}{r}-5.10 \\
-8.65 \\
-7.93\end{array}$ \\
\hline 2 & $\begin{array}{l}-1.45 \\
-3.23 \\
-3.18\end{array}$ & $\begin{array}{l}3 \cdot 60 \\
4 \cdot 68 \\
4 \cdot 85\end{array}$ & $\begin{array}{l}1.13 \\
1.85 \\
2.48\end{array}$ & $\begin{array}{l}2 \cdot 20 \\
2.48 \\
3.53\end{array}$ & $\begin{array}{l}3 \cdot 20 \\
2 \cdot 18 \\
1 \cdot 10\end{array}$ & $\begin{array}{l}-0.35 \\
-0.38 \\
-1.93\end{array}$ \\
\hline 3 & $\begin{array}{l}4 \cdot 18 \\
7 \cdot 78 \\
7 \cdot 63\end{array}$ & $\begin{array}{l}4.55 \\
3.95 \\
3 \cdot 00\end{array}$ & $\begin{array}{l}3 \cdot 60 \\
6 \cdot 23 \\
7 \cdot 55\end{array}$ & $\begin{array}{l}1 \cdot 20 \\
0 \cdot 30 \\
0 \cdot 70\end{array}$ & $\begin{array}{l}0.80 \\
0.45 \\
1.53\end{array}$ & $\begin{array}{r}1.85 \\
0.68 \\
-0.40\end{array}$ \\
\hline 4 & $\begin{array}{l}-0.10 \\
-1.03 \\
-1.35\end{array}$ & $\begin{array}{l}1.90 \\
4.53 \\
7.03\end{array}$ & $\begin{array}{l}2 \cdot 88 \\
2 \cdot 05 \\
1 \cdot 93\end{array}$ & $\begin{array}{l}-2.48 \\
-0.88 \\
-1.93\end{array}$ & $\begin{array}{l}-6.98 \\
-5.93 \\
-7.13\end{array}$ & $\begin{array}{r}-5.08 \\
-10.95 \\
-11.73\end{array}$ \\
\hline 5 & $\begin{array}{r}6 \cdot 63 \\
8 \cdot 43 \\
10 \cdot 70\end{array}$ & $\begin{array}{l}2 \cdot 43 \\
2 \cdot 40 \\
1 \cdot 28\end{array}$ & $\begin{array}{r}0.48 \\
-1.45 \\
-0.08\end{array}$ & $\begin{array}{l}2 \cdot 63 \\
4.53 \\
5.00\end{array}$ & $\begin{array}{l}-5.20 \\
-7.23 \\
-7.58\end{array}$ & $\begin{array}{l}2 \cdot 35 \\
3.53 \\
3 \cdot 93\end{array}$ \\
\hline 6 & $\begin{array}{r}-0.95 \\
2.00 \\
2 \cdot 20\end{array}$ & $\begin{array}{l}1 \cdot 70 \\
3 \cdot 78 \\
4 \cdot 33\end{array}$ & $\begin{array}{l}-1.85 \\
-6.28 \\
-6.03\end{array}$ & $\begin{array}{l}-1.28 \\
-1.40 \\
-1.85\end{array}$ & $\begin{array}{r}0.35 \\
-6.90 \\
-6.43\end{array}$ & $\begin{array}{r}-9.08 \\
-12.10 \\
-12.65\end{array}$ \\
\hline & & $\begin{array}{c}\mathrm{Me} \\
- \\
- \\
-\end{array}$ & & $\begin{array}{l}\text { fean } F_{1} \\
+1.60 \\
+1.13 \\
+1.02\end{array}$ & & \\
\hline
\end{tabular}

ways. In the first analysis, following the method of Hayman (1954), estimates were made of the significance of differences between the mean effects of each parental line $(a)$, of the overall differences between progenies and their parental means $(b)$, and of consistent $(c)$ and inconsistent $(d)$ maternal effects. (b) can be subdivided further to give different components of dominance, $\left(b_{1}\right)$ indicating whether the parental and progeny means are different. The second analysis involves comparisons of the variances of array means $(\mathrm{Vr})$ and covariances within arrays of family means on to the non-recurrent 
parent means (Wr) (Jinks and Hayman, loc. cit.). Comparisons may also be made of $\mathrm{Wr}$ and co-variance within arrays of family means on to the mean of all offspring of that array $\left(\mathrm{W}^{1} \mathrm{r}\right)$ (Hayman, ${ }^{1958)}$. In all these calculations the mean values of the reciprocal families are used. If the $\mathrm{Wr} / \mathrm{Vr}$ and $\mathrm{W}^{1} \mathrm{r} / \mathrm{Wr}$ relationships are represented graphically, certain genetic information can be drawn from the distribution of the points representing each array on the graph. A random scattering of points about the origin implies no genetic differences among the parents for this character. In the case of the $\mathrm{Wr} / \mathrm{Vr}$ graph, dominance is revealed by the distribution of the points along a significant regression line. The degree of dominance is shown by the position of the intercept of the regression line on the:

TABLE 2

Analysis of variance of radiosensitivity

\begin{tabular}{|c|c|c|c|c|}
\hline Item & $\mathrm{N}$ & $\begin{array}{l}\text { Cotyledon length } \\
\text { mean square }\end{array}$ & $\begin{array}{l}\text { Ist leaf length } \\
\text { mean square }\end{array}$ & $\begin{array}{l}\text { 2nd leaf length } \\
\text { mean square }\end{array}$ \\
\hline $\begin{array}{l}a \\
b_{1} \\
b_{2} \\
b_{3} \\
b \\
c \\
d \\
\mathrm{~B} t\end{array}$ & $\begin{array}{r}5 \\
1 \\
5 \\
9 \\
15 \\
5 \\
10 \\
105\end{array}$ & $\begin{array}{c}\text { i1 } 7 \cdot 4^{* * *} \\
\text { 1 } 6 \cdot \cdot 7^{* * *} \\
26 \cdot 1 * * * \\
36 \cdot 2^{* * *} \\
38 \cdot 2^{* * *} \\
80 \cdot 6^{* * *} \\
29 \cdot 9^{* * *} \\
4 \cdot 43\end{array}$ & $\begin{array}{l}249 \cdot 8^{* * * *} \\
56 \cdot 9 \\
48 \cdot 3 \\
75 \cdot 1 * * \\
64 \cdot 9^{* * *} \\
160 \cdot 8^{* * *} \\
79 \cdot 9^{* * *} \\
22 \cdot 3\end{array}$ & $\begin{array}{c}270 \cdot 7^{* * *} \\
47 \cdot 2 \\
68 \cdot 8^{* *} \\
91 \cdot 5^{* * *} \\
80 \cdot 9^{* * *} \\
194 \cdot 6^{* * *} \\
80 \cdot 7^{* * *} \\
21 \cdot 4\end{array}$ \\
\hline Total & 140 & & & \\
\hline
\end{tabular}

$\mathrm{Wr}$ axis. Interaction is revealed on the $\mathrm{Wr} / \mathrm{Vr}$ graph by a deviation of the best fitting regression line from a slope of $\mathrm{I}$, and in the case of the $\mathrm{W}^{1} \mathrm{r} / \mathrm{Wr}$ graph, by a deviation from a slope of 0.5 . The position of a point on the regression line reflects the relative number of dominant to recessive genes in the common parent of the array-the nearer to the origin the greater the proportion of dominant alleles.

A. Cotyledon length. Table 2 gives the results of the analysis of variance of cotyledon data. A Bartlett's test of heterogeneity of block interactions wás not significant $\left(\chi_{(5)}^{2}=3.01 ; P=0.7\right.$ to 0.5$)$, and so the main components were tested against a common error variance. The significance of $(a)$ indicates differences between the mean effects of the parental lines; $\left(b_{1}\right)$ tests if there is a significant excess of dominance in one direction, and $\left(b_{2}\right)$ and $\left(b_{3}\right)$ indicate the occurrence of dominance. The mean parental value was -8.03 and that of the progenies $+\mathrm{I} \cdot 6 \mathrm{o}$, indicating an overall greater average radiosensitivity of hybrids than of parents. An unusual feature was the very marked consistent maternal effect $(c)$ and non-consistent maternal effect $(d)$. 
The zero error for the sums of squares between blocks was due to the fact that deviations from the regression lines were used as the metric, and all the deviations must add up to zero.
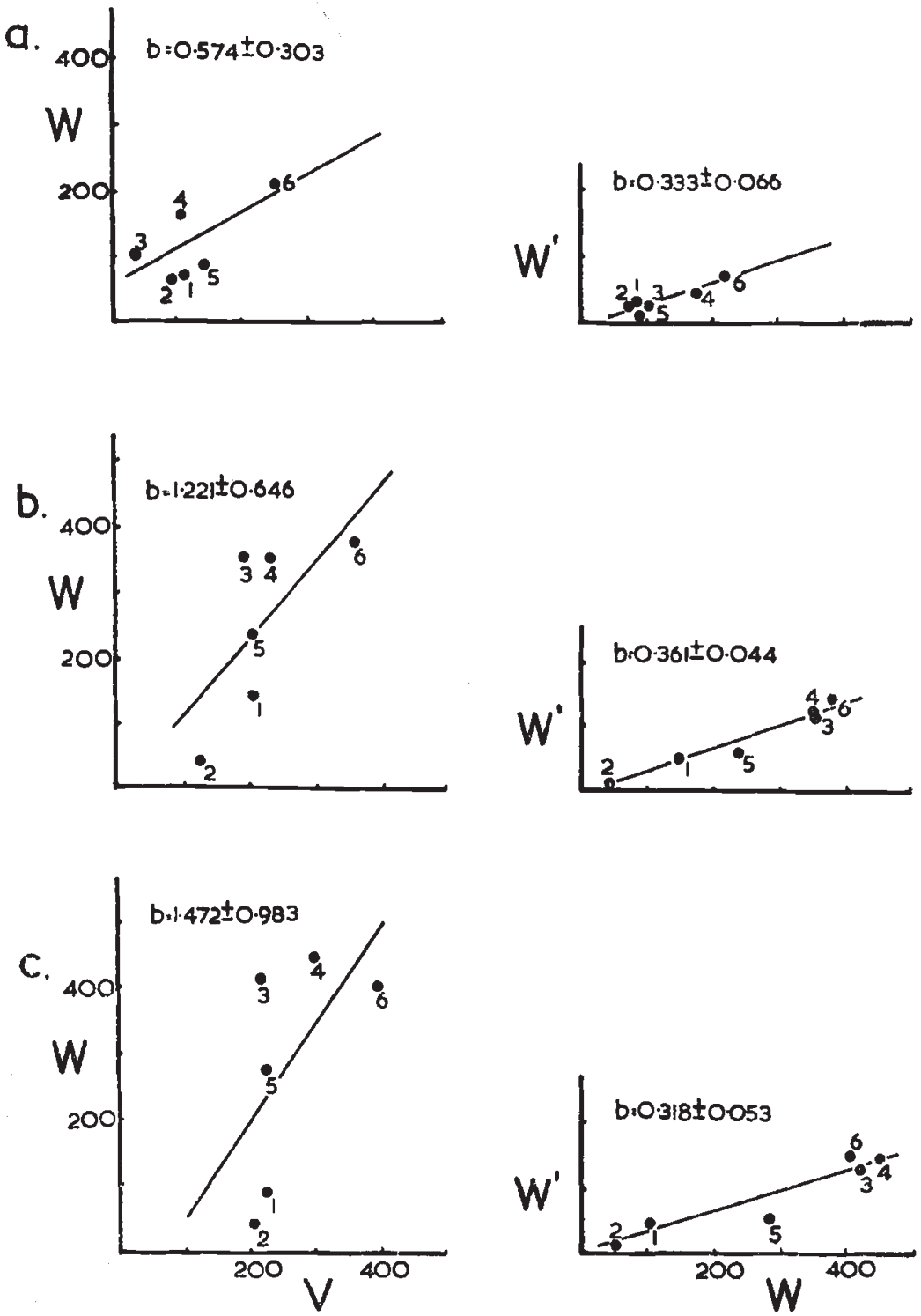

Fic. 1.-Wr/ $\mathrm{Wr}$ and $\mathrm{W}^{\mathbf{l}} \mathrm{r} / \mathrm{Wr}$ graphs from the diallel analyses, for radiosensitivity. The numbers indicate the various genotypes used in the experiment. The significance of the relationships was determined by joint regression tests, whereas the slopes and standard errors of the regression lines were calculated from the mean values for all four blocks in the experiment. a, Cotyledons; b, first leaves; c, second leaves.

A joint regression test of the $\mathrm{Wr} / \mathrm{Vr}$ relation showed it to be highly significant $(\mathrm{P}<\mathrm{O} \cdot 0 \mathrm{O})$ (fig. I). There was no significant heterogeneity between regressions, and the regression means of the different blocks 
were not significantly different. The slope of the regression line for the mean values for all blocks, $b=0.574 \pm 0.303$, did not represent a significant deviation from I $(\mathrm{P}=0 \cdot 3$ to 0.2$)$, and the line passed through a point which did not deviate significantly from the origin $(P=0.2$ to 0.1$)$. This significant regression line of slope I passing through the origin suggested the occurrence of dominance. There was no evidence of the presence of over-dominance or of non-allelic interaction. The joint regression for $\mathrm{W}^{1} \mathrm{r} / \mathrm{Wr}$ was again very significant $(\mathrm{P}<0.00 \mathrm{I})$, $b=0.333 \pm 0.066$, the value of $b$ agreeing with a slope of $0.5(\mathrm{P}=$ 0.1 to 0.05$)$. This line could also be regarded as passing through the origin $(\mathrm{P}>0 \cdot 9)$. The position of the parents on the $\mathrm{Wr} / \mathrm{Vr}$ and $\mathrm{W}^{1} \mathrm{r} / \mathrm{Wr}$ graphs showed that arrays 6 and 4 had most of the recessive alleles.

Though the joint regression test for $\mathrm{Wr} / \mathrm{Vr}$ was significant, the slope of the line was low and the errors high and there were obviously factors upsetting the $\mathrm{Wr} / \mathrm{Vr}$ relationship. In other words, the inheritance of this character was not simple. Low heritability could cause a poor distribution of array points, but the evidence from the initial analysis of variance showed that there was a significant heritable component. There was no real evidence of interaction or of unequal gene distribution, though there was some evidence of curvature in the $\mathrm{Wr} / \mathrm{Vr}$ relationship. What was much more likely was that the very strong consistent and inconsistent maternal effects observed in the initial analysis were having an effect on the $\mathrm{Wr} / \mathrm{Vr}$ relationships. The $\mathrm{W}^{1} \mathrm{r} / \mathrm{Wr}$ relationship is generally considered to be less sensitive to upsets than the $\mathrm{Wr} / \mathrm{Vr}$ relationship. If the true nuclear genetic situation was being masked by the consistent maternal effect (c), than an analysis of the data from rows (common female parent) and columns (common male parent) separately should give useful information; in theory, information from the data obtained from the rows should be less disturbed than that from coluinns. $\mathrm{Wr} / \mathrm{Vr}$ and $W^{1} \mathbf{r} / \mathrm{Wr}$ relationships for rows and columns were determined, but it was found that these did not provide a significant regression linein other words, the relationship for rows and for columns was worse than that for the summed reciprocal families. All this information indicated that the $(c)$ component could not entirely account for the upsetting of the $\mathrm{Wr} / \mathrm{Vr}$ relationship, but rather that the $(d)$ component was particularly important. Yet the upsetting influence of $(d)$ was less apparent when mean values for families were summed over reciprocals, as a significant $\mathrm{Wr} / \mathrm{Vr}$ regression was then obtained. It was also of interest to note that the apparent position of the array points varied in the row, column and summed reciprocal family graphs, indicating that maternal effects could influence apparent dominance relationships. Definite evidence substantiating this observation was obtained in a later analysis.

More detailed analyses and an estimation of genetic paraineters from second degree statistics (Mather, 1949) were not considered justified in view of the pronounced maternal effects found. 
B. First and second leaf lengths. The mean values and results of the analyses of variance are given in tables $I$ and 2 . The data are similar to those from the cotyledons in that there was evidence of variability between parents, of dominance, and of pronounced consistent and non-consistent maternal effects. The only difference found was in the case of the $\left(b_{1}\right)$ component--for the first and second leaf lengths there was evidence of balanced dominance. The $\mathrm{Wr} / \mathrm{Vr}$ and $W^{1} r / W r$ graphs are shown in fig. I; the analyses of the joint regression lines showed both to be significant $(\mathrm{P}<\mathrm{O} \cdot 00 \mathrm{I})$. There was again no evidence of heterogeneity over blocks, and in only one instance was there a doubtful suggestion of a difference in the regression means. Though the joint regression test was significant, the value of $b$ and the errors were high, and there was a lack of proportionality between array variance and co-variance ( $\mathrm{Vr}$ and $\mathrm{Wr}$ ). This could in theory be accounted for by a heterogeneity in the error variances of the array variances, but a Bartlett's test showed them to be homogeneous $(\mathrm{P}=0.7$ to 0.5$)$. Separation of the data into rows and columns and subsequent analysis of the data in this form did not materially improve the $\mathrm{Wr} / \mathrm{Vr}$ relationships, again indicating the importance of the $(d)$ component. The $\mathrm{W}^{1} \mathrm{r} / \mathrm{Wr}$ joint regression lines from these two characters did deviate significantly from a slope of 0.5 (fig. I) ( $\mathrm{P}<0.001$ for the first leaves and $\mathrm{P}=0.05$ to 0.02 for the second leaves) indicating some form of interaction. However, no definite conclusions can be drawn from the variance and covariance relationships as these were obviously again being upset to a very marked degree. The position of points again appeared to change according to whether data from rows, columns or reciprocal families were used. Arrays 6, 4 and 3 had most recessive alleles.

\section{(ii) The control characters}

The mean values and results of the analyses of variance for control characters-cotyledon length, first and second leaf lengths, are given in tables 3 and 4 . There was evidence of differences between the parents for all three characters, no heterosis, but some evidence of dominance, especially for cotyledon length. The maternal effects were nowhere as pronounced for this character as for radiosensitivity. That maternal effects were important was, however, obvious when (a) was recalculated for rows and for columns separately. The differences between arrays for rows would include inherent genetic differences as well as differences due to maternal effects, and these could cancel each other out. This in fact did occur, and the sums of squares for rows (table 4) was in every instance much smaller than that for columns. The differences between columns would be due to the nuclear genetic differences only. The two new (a) values calculated should equal the sum of $(a)$ and $(c)$ calculated from the summed reciprocal families. Thus again we had a situation in which the true nuclear genetic and cytoplasmic controls were possibly being 
TABLE 3

The mean values for the controls. The first refers to the cotyledons, and the second and third to the first and second leaves respectively

\begin{tabular}{|c|c|c|c|c|c|c|}
\hline & \multicolumn{6}{|c|}{ Male } \\
\hline & I & 2 & 3 & 4 & 5 & 6 \\
\hline$\underset{I}{\text { Female }}$ & $\begin{array}{l}58 \cdot 68 \\
6 \mathrm{r} \cdot 38 \\
55 \cdot 65\end{array}$ & $\begin{array}{l}44 \cdot 53 \\
45 \cdot 80 \\
29 \cdot 70\end{array}$ & $\begin{array}{l}52 \cdot 90 \\
60 \cdot 93 \\
50 \cdot 95\end{array}$ & $\begin{array}{l}5^{1} \cdot 55 \\
5^{2} \cdot 00 \\
39^{\circ} \cdot 03\end{array}$ & $\begin{array}{l}57 \cdot 23 \\
53 \cdot 18 \\
44 \cdot 58\end{array}$ & $\begin{array}{l}53.40 \\
59^{\circ} 5^{\circ} \\
5^{\circ} \cdot 5^{\circ}\end{array}$ \\
\hline 2 & $\begin{array}{l}45 \cdot 98 \\
53 \cdot 28 \\
4^{1} \cdot 20\end{array}$ & $\begin{array}{l}58 \cdot 15 \\
60 \cdot 85 \\
55 \cdot 88\end{array}$ & $\begin{array}{l}55 \cdot 58 \\
60 \cdot 73 \\
50 \cdot 18\end{array}$ & $\begin{array}{l}51 \cdot 38 \\
46 \cdot 40 \\
37 \cdot 15\end{array}$ & $\begin{array}{l}60 \cdot 08 \\
59 \cdot 33 \\
49 \cdot 35\end{array}$ & $\begin{array}{l}60 \cdot 08 \\
59 \cdot 63 \\
48 \cdot 63\end{array}$ \\
\hline 3 & $\begin{array}{l}39 \cdot 33 \\
45 \cdot 08 \\
30 \cdot 08\end{array}$ & $\begin{array}{l}50 \cdot 28 \\
56 \cdot 90 \\
45 \cdot 03\end{array}$ & $\begin{array}{l}52 \cdot 40 \\
61 \cdot 43 \\
53 \cdot 33\end{array}$ & $\begin{array}{l}49^{\cdot} 83 \\
5^{2} \cdot 03 \\
4^{1} \cdot 5^{0}\end{array}$ & $\begin{array}{l}56 \cdot 58 \\
59 \cdot 63 \\
51 \cdot 98\end{array}$ & $\begin{array}{l}57 \cdot 23 \\
60 \cdot 78 \\
49 \cdot 08\end{array}$ \\
\hline 4 & $\begin{array}{l}50 \cdot 80 \\
51 \cdot 70 \\
40 \cdot 80\end{array}$ & $\begin{array}{l}60 \cdot 35 \\
53 \cdot 85 \\
49 \cdot 53\end{array}$ & $\begin{array}{l}45 \cdot 28 \\
51 \cdot 98 \\
41 \cdot 98\end{array}$ & $\begin{array}{l}56 \cdot 23 \\
50 \cdot 43 \\
39 \cdot 90\end{array}$ & $\begin{array}{l}57.75 \\
56.65 \\
48.05\end{array}$ & $\begin{array}{l}5 I \cdot 03 \\
57 \cdot 73 \\
47 \cdot 75\end{array}$ \\
\hline 5 & $\begin{array}{l}54 \cdot 55 \\
56 \cdot 93 \\
47 \cdot 55\end{array}$ & $\begin{array}{l}53 \cdot 68 \\
56 \cdot 23 \\
40 \cdot 35\end{array}$ & $\begin{array}{l}52 \cdot 83 \\
58 \cdot 85 \\
47 \cdot 33\end{array}$ & $\begin{array}{l}53 \cdot 78 \\
52 \cdot 03 \\
37 \cdot 60\end{array}$ & $\begin{array}{l}49 \cdot 30 \\
49 \cdot 55 \\
39 \cdot 90\end{array}$ & $\begin{array}{l}60 \cdot 08 \\
62 \cdot 85 \\
53 \cdot 60\end{array}$ \\
\hline 6 & $\begin{array}{l}54 \cdot 53 \\
50 \cdot 95 \\
43 \cdot 55\end{array}$ & $\begin{array}{l}55 \cdot 85 \\
58 \cdot 50 \\
48 \cdot 33\end{array}$ & $\begin{array}{l}54 \cdot 53 \\
62 \cdot 03 \\
53 \cdot 75\end{array}$ & $\begin{array}{l}52 \cdot 75 \\
5 \mathrm{I} \cdot 63 \\
37 \cdot 80\end{array}$ & $\begin{array}{l}5^{0} \cdot 75 \\
59^{\prime} 10 \\
5^{\circ} \cdot 80\end{array}$ & $\begin{array}{l}50 \cdot 90 \\
5^{\mathrm{I}} \cdot 4^{8} \\
4^{\mathrm{I}} \cdot 55\end{array}$ \\
\hline
\end{tabular}

TABLE 4

Analysis of variance of leaf length

\begin{tabular}{|c|c|c|c|c|}
\hline Item & $N$ & $\begin{array}{l}\text { Cotyledon length } \\
\text { mean square }\end{array}$ & $\begin{array}{l}\text { Ist leaf length } \\
\text { mean square }\end{array}$ & $\begin{array}{l}\text { 2nd leaf length } \\
\text { mean square }\end{array}$ \\
\hline $\begin{array}{l}a \\
b_{1} \\
b_{2} \\
b_{3} \\
b \\
c \\
d \\
\mathrm{~B} \\
\mathrm{~B} t\end{array}$ & $\begin{array}{r}5 \\
1 \\
5 \\
9 \\
15 \\
5 \\
10 \\
3 \\
105\end{array}$ & $\begin{array}{l}89 \cdot 9^{* * *} \\
26 \cdot 2 \\
183 \cdot 3^{* * *} \\
81 \cdot 2^{* * *} \\
111 \cdot 5^{* * *} \\
40 \cdot 7 \\
81 \cdot 6 * * * \\
67 \cdot 7^{*} \\
19 \cdot 5\end{array}$ & $\begin{array}{c}191 \cdot 3^{* *} \\
1 \cdot 98 \\
235 \cdot 5^{* *} \\
23 \cdot 9 \\
92 \cdot 9 \\
86 \cdot 7 \\
66 \cdot 6 \\
1091 \cdot 3^{* * *} \\
58 \cdot 2\end{array}$ & $\begin{array}{l}219.3^{*} \\
154.5 \\
407.5 * * * \\
60.4 \\
182 \cdot 4^{* *} \\
187.8^{*} \\
135.8 \\
1394.3^{* * *} \\
74.8\end{array}$ \\
\hline $\begin{array}{l}\text { Total } \\
a \text { rows } \\
a \text { columns }\end{array}$ & 143 & $\begin{array}{l}46 \cdot 98 * \\
85 \cdot 78^{* *}\end{array}$ & $\begin{array}{c}22 \cdot 30 \\
253 \cdot 5^{8 * * *}\end{array}$ & $\begin{array}{c}23 \cdot 04 \\
384 \cdot 15 * * *\end{array}$ \\
\hline
\end{tabular}


masked due to their complementary actions. Analyses of the relationships of $\mathrm{Wr}$ and $\mathrm{Vr}$ and of $\mathrm{W}^{1} \mathrm{r}$ and $\mathrm{Wr}$ showed no significant joint regression in any instance. Here again, this was not due to a lack of genetic differences or to environmental error variation, but to consistent or non-consistent maternal effects, or to nuclear gene interaction. All joint regressions for rows and columns were also not significant.

\section{(iii) The comparison of radiosensitivity and of the control characters}

The ultimate aim in this experiment, having now shown that there were heritable differences between parental lines in terms of radiosensitivity, was $(a)$ to compare the control of the characters at the different stages in the plant's development (cotyledons, first and second leaves) and $(b)$ to determine whether there was a different control of radiosensitivity and of growth (the control characters above). The analysis of Allard (1956) was adapted for this purpose. This analysis is concerned with the relative magnitudes of $\mathrm{Wr}$ and $\mathrm{Vr}$ under different conditions, and will test the significance of variation due to dominance, (D, difference between $\mathrm{Wr}$ and $\mathrm{Vr}$ ) and to arrays, A. A significant dominance component can be expected, except when dominance is complete. The array component detects differences in the proportion of dominant and recessive alleles between parents. The analysis was also adapted to test for differences between rows and columns, and between blocks. Dominance and array components can be estimated for the two characters, radiosensitivity and control values, for the three stages at which the effects were measured, and for differences in their expression in rows and columns. Other interactions are of interest also-for example, a significant dominance $\times$ arrays component usually indicates non-allelic interaction. Information such as this could substantiate the tentative conclusions drawn from the earlier inconclusive analyses.

The analysis of variance is given in table 5 . When all the data were taken together there was evidence of incomplete dominance (D) and of differences between leaves (L). The proportion of dominant alleles in the various genotypes was different for radiosensitivity and the control character $(\mathrm{A} \times \mathrm{C})$; the mean dominance values also differed for the two characters $(D \times C)$-in fact, this was one of the largest components of variation. Mean dominance also varied in the three leaves examined $(\mathrm{D} \times \mathrm{L})$. Significant higher order interactions (ABCL), (DBCL) and (ADRBC) showed that all main effects were important and were interacting in a complex manner. Since such marked interactions were found, the data were split and analyses undertaken separately of data from the irradiated, control, cotyledon, first and second leaf series. Again the high order interactions ADRB in the irradiated and control series were significant. In the irradiated data of particular interest was the interaction $(A \times R)$, indicating a difference in the apparent proportion of dominant alleles found in 
rows and columns. This difference substantiated the results of the initial analyses of variance where maternal effects ( $c$ and $d$ components) were particularly pronounced. From these data also it was shown

TABLE 5

Analysis of variance of $\mathrm{Wr}$ and $\mathrm{Vr}$

\begin{tabular}{|c|c|c|c|}
\hline \multicolumn{4}{|c|}{ Total } \\
\hline Item & & $\mathbf{N}$ & Mean squuare \\
\hline $\begin{array}{l}\text { Arrays } \\
\text { Dominance } \\
\text { Rows and columns } \\
\text { Blocks } \\
\text { Character } \\
\text { Leaves }\end{array}$ & $\begin{array}{l}\text { (A) } \\
\text { (D) } \\
\text { (R) } \\
\text { (B) } \\
\text { (L) }\end{array}$ & $\begin{array}{l}5 \\
1 \\
1 \\
3 \\
1 \\
2\end{array}$ & $\begin{array}{c}207,921 \\
18,988,206 * * * \\
25,783 \\
1,413,068 \\
2,596,650 \\
3,714,054^{* * *}\end{array}$ \\
\hline $\begin{array}{l}\mathbf{A} \times \mathbf{B} \\
\mathbf{A} \times \mathbf{C}\end{array}$ & : & $\begin{array}{r}35 \\
5\end{array}$ & $\begin{array}{l}37^{6}, 4^{60 * * *} \\
54^{8}, 054^{* * *}\end{array}$ \\
\hline $\begin{array}{l}\mathrm{D} \times \mathrm{B} \\
\mathrm{D} \times \mathrm{C} \\
\mathrm{D} \times \mathrm{L}\end{array}:$ & : & $\begin{array}{l}3 \\
1 \\
2\end{array}$ & $\begin{array}{c}547,365^{* *} \\
5,651,930^{* * *} \\
985,523^{*}\end{array}$ \\
\hline $\begin{array}{l}\mathrm{B} \times \mathrm{C} \\
\mathrm{B} \times \mathrm{L}\end{array}$ & . & $\frac{3}{6}$ & $\begin{array}{l}802,324^{* * *} \\
297,016^{*}\end{array}$ \\
\hline $\begin{array}{l}\mathrm{A} \times \mathrm{B} \times \mathrm{C} \times \mathrm{I} \\
\mathrm{D} \times \mathrm{B} \times \mathrm{C} \times \mathrm{L}\end{array}$ & . & $\begin{array}{r}30 \\
6\end{array}$ & $\begin{array}{r}83,386^{*} \\
127,940^{*}\end{array}$ \\
\hline $\mathrm{A} \times \mathrm{D} \times \mathrm{R} \times \mathrm{B} \times \mathrm{C}$ & . & I5 & $146,755^{*}$ \\
\hline Others non-significan & nt & 476 & 100,746 \\
\hline Residual & . & 30 & 62,277 \\
\hline Total & . & 575 & \\
\hline
\end{tabular}

that the proportion of dominants and degree of mean dominance varied according to the leaf in which the measurements were made $(\mathrm{A} \times \mathrm{L})$ and $(\mathrm{D} \times \mathrm{L})$.

\section{DISCUSSION}

The manner in which tomato seeds responded to ${ }^{\circ 0} \mathrm{Co}$ gamma rays was shown to be under genetic control, but the exact nature of this control was difficult to elucidate because of its complexity. There was evidence of additivity and dominance, with the different genotypes used in the experiment exhibiting different proportions of dominant 
and recessive alleles, and of consistent and non-consistent maternal effects. There was evidence of heterosis for sensitivity in some crosses, and for resistance in others.

The complexity of the control could to a large extent be accounted for by the pronounced maternal effects, and unsuccessful attempts were made to remove them from the analyses by examining the data from rows (common female parent) and columns (common male parent) separately. The lack of success was probably attributable to a large extent to the importance of the non-consistent maternal effects. Of particular interest was the novel observation of the maternal influence on the apparent proportions of dominant and recessive alleles in the different genotypes (table 5). The complexity of the genetical control could possibly in part be attributable to the occurrence of nuclear gene interaction, but there was no means of ascertaining this in the presence of the pronounced upsetting influence of the maternal effects. One can only speculate as to the nature of the maternal effects. They could be due to the influence of the endosperm or to true cytoplasmic effects. An influence of the endosperm might be expected, since seedling characters were scored. However, it is conceivable that even if mature characters were scored this endosperm effect would still be recognised, since the initiating event which results in radiation damage occurs in the embryo stage with seed irradiation.

The genetical control of radiosensitivity was different from that of the simple growth characters, though there was some similarity in that both showed maternal effects. There was also evidence that the control of these characters varied according to whether they were measured in the cotyledon, first or second leaf. Such a difference might be expected for the growth character, with different gene systems being activated at the various stages in the differentiation of the plant. In the case of radiosensitivity, there is only a single common event occurring at the seed stage, and this results in damage in the cotyledons, first and second leaves. It might therefore be expected that the genetical control would appear similar, irrespective of the tissue in which it was measured. The dissimilarity could be due to an elimination of damaged cells in the meristems, thus giving rise to different measures of damage at the different stages of growth. The rate of elimination would vary according to the genotype. On the other hand, if it is assumed that different gene systems are concerned with growth at the various stages, then all these systems need not necessarily be damaged to the same extent. In his studies of radiosensitivity in mice, Grahn (1958) has also indicated that an incomplete picture of the genetical control is derived if only a single level of response is used.

The dominance detected in respect of radiation response was shown to bc ambidirectional for the first and second leaves. Since dominance is a condition which evolves (Fisher, 1930), the ambidirectional dominance implies that selection for the character radiosensitivity has 
been of a stabilising nature (Mather, 1943; Breese and Mather, 1960). Before discussing this observation further, it is necessary to consider whether there is any relation between spontaneous mutation and chromosome breakage, and induced mutation and breakage (which is ultimately what is measured when growth reduction is scored). If these are comparable, and there is no unequivocal evidence on this point, then it is conceivable that a low level of spontaneous mutation and breakage in an organism has a selective advantage as a means of providing variability. Too low and too high rates would be disadvantageous and hence selection would be of a stabilising kind. On the other hand, if induced and spontaneous mutation and breakage are not comparable, then the character, radiation response, is onc which cannot have been exposed to selection. In other words, radiosensitivity per se is not a true character, and what in fact has been measured is some quite different character. This could control such factors as oxygen tension, metabolic rate or production of radioprotective substances etc., and different levels of expression of this character could result in different levels of radiosensitivity. The selection pressure on this unknown character can, of course, not be elucidated.

\section{SUMMARY}

The response of tomato seeds to gamma radiation was shown to be genetically controlled. The nature of this control was investigated by an analysis of the progenies of a diallel cross of six varieties. It was polygenic, with evidence of additivity and dominance. The different varieties had various proportions of dominant and recessive alleles, and dominance was ambidirectional. Pronounced consistent and inconsistent maternal effects influenced the radiation response; these affected dominance values to produce a complex genetical situation. The control of radio-sensitivity and growth characters was different, and the genetical situation varied according to the stage of growth at which the characters were measured.

Acknowledgments.-I am indebted to Professor K. Mather and Dr J. L. Jinks for their comments, to $\mathrm{Mr} \mathrm{B}$. Cooper for drawing up programmes for the Harwell Mercury Computer for the analyses of variance, and to Dr C. W. Lawrence for numerous helpful discussions.

\section{REFERENCES}

AILARD, R. W: 1956. The analysis of genetic-environmental interactions by means of diallel crosses. Genetics, $41,305-318$.

BREESE, E. L., AND MATHER, K. I96o. The organisation of polygenic activity within a chromosome in Drosophila II viability. Heredity, 14, 375-399.

Fisher, R. A. 1930. The Genetical Theory of Natural Selection. Clarendon Press, Oxford.

GRAHN, D. r958. The genetic factor in acute and chronic radiation toxicity. Proc. 2nd Int. Conf. on Peaceful Uses of Atomic Energy, 22, 394-399.

HAYMaN, B. I. 1954. The analysis of variance of diallel tables. Biometrics, 10, 235-244. 
hayman, B. 1. 1958. The theory and analysis of diallel crosses, II. Genetics, 43, $63-85$.

JINKs, J. L. 1954. The analysis of continuous variation in a diallel cross of Nicotiana rustica varieties. Genetics, 39, 767-788.

JiNks, J. L., AND hayman, B. I. 1953. The analysis of diallel crosses. Maize Genetics, Coop. News Letter, 27, 48-54.

Mather, K. 1943. Polygenic inheritance and natural selection. Biol. Revs., 18, $32-64$.

MATHER, K. 1949. Biometrical Genetics. Methuen, London.

sмrтн, L. 1942. Hereditary susceptibility to X-ray injury in Triticum monococcum. Amer. Four. Bot., 29, 189-192. 